\title{
MEDIA RELATIONS STRATEGY IN PROMOTING DESTINATION OF KUTANG BEACH OF LAMONGAN DISTRICT, INDONESIA
}

\author{
Afifatur Rohimah', Yunita Ardilla' ${ }^{2}$, Moh. Khoirul Anam ${ }^{3}$ \\ ${ }^{123}$ Sunan Ampel State Islamic University, Surabaya \\ 1afifatur.rohimah@uinsby.ac.id, 2yunita.ardilla@uinsby.ac.id, \\ ${ }^{3}$ moh.khoirul.anam@uinsby.ac.id
}

\begin{abstract}
Tourism becomes a wealth that will not run out otherwise tourism will continue to grow if the management is getting better. Media relations becomes one of the alternatives in helping the promotion process of a tourist destination. This study aims to analyze the media relations strategy in promoting tourist destinations that focus on the Kutang beach district Lamongan. This research applies a qualitative naturalistic method where there is no manipulation of an event (background) of research. The result of this research is the use of media relations to be one of the main components in improving the development of coastal tourism destinations. Use of media relations applied: 1) Press Release Activity, 2) Conference Press, 3) Event, 4) Press Message. Some of these activities carried out by involving the community, managers, government, and tourists, so that the implementation of media relations activities can be maximized. Some media relations activities that have been carried out are press release activities, press conferences, special events. One of which dominating is a special event because it is considered by the speaker as a simple activity that is able to have a tremendous impact, with the event, media partners from themselves will involve themselves in the event activities. Besides conducting media relations, it is also necessary to establish segmentation and clear segmenting. It is also necessary to do tourism differentiation to create sustainable tourism.
\end{abstract}

\section{Keywords: Media relations, Promotion, Tourism, Beach Destinations}

\begin{abstract}
Abstak: Pariwisata menjadi sebuah kekayaan yang tidak akan habis sebaliknya pariwisata akan terus berkembang apabila dilakukan pengelolaan yang semakin bagus. Media relations menjadi salah satu alternatif dalam membantu proses promosi sebuah destinasi wisata. Penelitian ini bertujuan untuk menganalisis strategi media relations dalam mempromosikan destinasi wisata yang berfokus di pantai kutang kabupaten Lamongan. Penelitian ini menerapkan metode naturalistik kualitatif dimana tidak ada manipulasi sebuah peristiwa (latar) penelitian. Hasil penelitian yag didapatkan adalah penggunaan media relations menjadi salah satu komponen utama dalam peningkatan perkembangan destinasi wisata pantai kutang. Penggunaan media relation yang diterapkan : 1) Aktifitas Press Release, 2) Pers Konferensi, 3) Event, 4) Press Message. Beberapa kegiatan tersebut dilaksanakan dengan melibatkan masyarakat, pengelola, pemerintahan, serta wisatawan, sehingga pelaksanaan kegiatan media relation dapat maksimal. Beberapa kegiatan media relation yang telah dilaksanakan adalah aktifitas press release, konferensi pres, special event, yang mendominasi adalah special event karena dianggap narasumber sebagai aktifitas sederhana yang mampu memberikan dampak luar biasa, dengan event, rekan media dari dengan sendirinya akan melibatkan diri dalam kegiatan event tersebut.Selain melakukan media relasi, perlu juga dilakukan penetapan segmentasi dan terageting yang jelas. Perlu juga dilakukan diferensiasi wisata untuk memapu menciptakan wisata yang berkelanjutan
\end{abstract}

Kata Kunci : Media Relasi, Promosi, Pariwisata, Wisata Pantai 


\section{A. Introduction}

Tourism management should be done by correlated management that utilizes digitalization. Media relation strategy is still an interesting study in tourism promotion activities. It is undeniable that promotional activities are very dependent on the development of the media (Joep:2014). Consideration of the location and attractive identity of tourist attractions also contributes greatly in determining the existence of tourist attractions. One of the interesting beach tourist sites in east Java is Kutang beach. The uniqueness of the name becomes one of the specialties of the beach location. Therefore, the author thinks that there is a need to review further related to media relations strategy in promoting a tourist location in hopes of being able to grow sustainable tourism.

Media relation strategy is still one of the government's flagship strategies in promotional activities. Of course, this is not an excuse, the study by Sawitri (Sawitri:2017) states that media relations strategies play an important role as well as key in promotional activities. When looking further, of course, there are promotional activities such as organizing events, profiling, to making several announcements all using a media. This is what makes Kayely think that promotion has a heavy reliance on media relations strategies. ${ }^{1}$ Kriyantono also claims that a counter-action will not be maximal if there is no effort to use media. ${ }^{2}$ Seeing the large role of media relations in promotional activities, the author assumes that it needs to study media relations in the promotion activities of a tourist spot.

Tourism is not only one of the cogs of a country's economy. Tourist attractions become one of the identities of a country, even in some countries become a benchmark of the existence and strength of a country. ${ }^{3}$ The magnitude of the role of tourism in the progress of a country is only one of the reasons the authors conducted this study. Another important consideration is that tourism in a particular location even becomes the main source of income of the community. Bali, for example, becomes one of the provinces in Indonesia that have a very high dependence on tourism. If the study of tourism promotion is not carried out sustainably, it will have an impact on the development of tourism. Another consideration is that in the future, the tourism sector becomes one of the mainstay economic sectors in the future because other economic sectors such as mining, petroleum, industry will have utilization thresholds. The longer all sectors will be depleted and cannot be reproduced. While tourism does not, the longer and more managed it actually provides higher benefits.

Indonesia is a country with thousands of islands scattered from the eastern to the western downstream with 34 culturally diverse province. ${ }^{4}$ The Government is managing seriously the tourist line as the main source of opinion of the Republic of Indonesia. The tourism sector is regulated in Law Number 10 Year 2009 on Tourism, in article 3 it is explained that tourism serves to meet the physical, spiritual and intellectual needs of every tourist with recreation and travel and increase country income to realize the welfare of society.

East Java becomes one of the local areas that have the diversity of coastal tourism, one of the regencies that have the characteristic of the north coast is Lamongan district which is a district located on the north coast of East Java. Based on the article Kustadi in an online portal write that there are 20 new tourist destinations classified in the district Lamongan, where most of which are the coastal tourism that becomes the main tourist destinations such as Kutang beach, frog beach,

\footnotetext{
${ }^{1}$ H. Kayely, Lagarense, B., Lumettu, A., Manado, P. N., \& Manado, P. N. "The Development Strategy of Tourist Attractions for Promoting Tourism Development". Jurnal Hospitaliti dan Pariwisata 3, no.2. (2016). Pp.114-232

2 R. Kriyantono. "Research Strategies and Media Relations in Public Relations Practices". Jurnal Komunikatif, 8. (2019): 178-190.

${ }^{3}$ Asmawaty. "Beach Tourism Destinations Promotion Strategy Tthrough Social Media Influencers in Bulukumba Regency”. International Journal of Papier Review 2, no.4. (2021). 56-69.

${ }^{4}$ K. D. Cahaya Putra. "Strategi Public Relations Pariwisata Bali". Jurnal Ilmu Komunikasi, 5. (2013).
} 
Brondong beach, in addition to coastal tourism potential as well as many historical tours, religious tourism, to entertainment tours. ${ }^{5}$

Kutang beach is one of the famous beach tourisms because of its controversial name. Geographically it is located in the village of Kentong, Labuhan village, Brondong district, north of regency of Lamongan. Kutang beach has a small wave characteristic because it is in the waters of the north coast. The name of the beach credits becomes rapidly skyrocketed when its name becomes known to tourists. The pedigree itself in the Javanese language is a woman's underwear which means or breast house in English. The name of the beach itself is not for no reason but this beach is often visited by youth and without any reason why they always leave their underwear as a relic of the traces they have visited there, so that the community gives the name of the Kutang beach. 6

In its development, Kutang beach has turned into a beach-friendly beach resort for families, has started to be managed professionally by local youth organization with various supportive files. With a rate of $\mathrm{Rp} 2,000$ tourists can enjoy the twilight edge of the beach, with wooden bridges painted in color increasingly increase the attractiveness, toilet facilities and parking space is still in the process of development, the Kutang beach more enticing with the impulse of mangrove embedded in the beach so more enthralling. The large number of attractions owned by the beach. The local community began to improve the management of a more professional in order to visit tourists also experience improvements in the hope to also improve the welfare of local communities.

Management of beach tourism has begun to take advantage of media debt as a media campaign. Media relation is being intensively exploited coastal cocktail management manager in a more professional management. Nurudin states that media relation becomes one of public relations activities that serves to brand, improve reputation, maintain public image, and create message messages to maximize the role of media. ${ }^{7}$ Real-time media can be used as creative approaches to enhance cooperation. The importance of media relations as a jack of one tourist destination. Based on these problems, the researcher wanted to know the media relation strategy in promoting the beach tourism destination of the district of Lamongan. The aim of the research is to know, analyze and describe the appropriate media relation strategy to promote Kutang beach as the main beach destination in regency of Lamongan.

\section{B. Theoretical Review}

\section{Marketing Communications}

The merger between communication and marketing studies will result in a study called Marketing Communication where this study aims to help the marketing activities of a company, communication and marketing is a unity that cannot be separated, because talking about marketing must be a very important communication role. According to Shimp, marketing communication is an important aspect in the integrity of marketing mission as well as determinants of marketing success. ${ }^{8}$

Terence A. Shimp marketing communications explains that marketing communication is an important aspect in the overall marketing mission as well as the determinant of marketing success. ${ }^{9}$ According to marketing communications expert Horold Lasswell in Effendy explains that the concept of marketing communication is able to answer the question "Who Says What in Which

\footnotetext{
${ }^{5}$ Kustadi. Public Relations Perusahaan: Kajian, Program, dan Implementasi. (Bandung: Yayasan Nuansa Cendekia, 2014).

${ }^{6}$ Firsan Nova. Strategi Public Relation: Menghadapi Krisis,Mengelola Isu, Membangun citra, dan Reputasi Perusahaan. (Jakarta: Rajawali Grafindo Persada, 2010).

${ }^{7}$ Nurudin. Hubungan Media Konsep dan Aplikasi. (Jakarta:Raja Grafindo Persada, 2018).

${ }^{8}$ Terence Shimp. Komunikasi Pemasaran Terpadu dalam periklanan dan Promosi. (Jakarta: Salemba Empa,. 2014).

${ }^{9}$ Ibid.
} 
Channel to Whom With What Effects?". ${ }^{10}$ While marketing communication has a marketing mix, according to Kotller and keller (Kotller and Keller:2008), among others:

1) Advertising is a presentation activity about ideas related to goods or services to a particular object that is not done by someone

2) Sales promotion is a short-term stimulus to increase the purchasing power of a product.

3) Public Relations and imaging is a program to form a positive image or image of a product

4) Personal selling is an information exchange between the seller and the prospective buyer directly, so the seller can describe the product directly and detail to the prospective buyer

5) Direct Marketing is the use of certain media to communicate with each other in the marketing rubric so that between sellers and buyers able to interact with each other.

Nickles revealed as cited by Wardhani that Marketing communication is a communication activity carried out by sellers and buyers and is an activity that helps in decision making in the field of marketing and directs exchanges to be more satisfactory by resuscitating all parties to do better. ${ }^{11}$ Marketing communication is a marketing activity that seeks to disseminate information, influence and persuade, and remind the target market of the company and its products to be willing to accept, use, and be loyal to the products offered by the company concerned. ${ }^{12}$ Marketing communications can be identified as:

1) Identifying the market and consumer needs or consumer perceptions.

2) Describe and operationalize the image or perception of the target company's objectives.

3) Evaluating a number of behaviors depicted is believed to achieve the goal.

In addition, managing marketing communications requires a design strategy and sales programs. According to Saladin Marketing communication is very important because: ${ }^{13}$

1) Can help customers with information that strengthens awareness and knowledge about the products or services offered.

2) Can affect customer attitudes and desires.

3) For companies, they can manage their service processes effectively and efficiently.

According to Deloier in Sulaksana in the book Synergy of Marketing Communication: ${ }^{14}$ Integration of advertising, public relations, and promotion, marketing communication is the process of delivering and blending stimuli to the target market that aims to generate response and interest in products and build channels to receive, interpret and take action on messages from the market by adjusting the company's current ideas and identifying new opportunities in communicating.

Marketing communication plays a very important role for marketers. Without marketing communication, consumers or society as a whole will not know the existence of the product in the market. Marketing communication also sucks up a very large budget therefore marketers must be careful and calculating and draw up a marketing communication plan. The determination of who is the target of communication determines the success of communication, with the right goal determination, the communication process will run effectively and efficiently. ${ }^{15}$

Based on the above definition it can be explained that marketing communication is an important aspect in the overall marketing mission as well as determinants of marketing success, ${ }^{16}$ therefore marketing communication for the tourism sector becomes very important. This makes the company obliged to build communication and relationships with its customers in order to

10 Onong Uchjana Effendy. Hubungan Masyarakat Suatu Study Komunikologis. (Bandung: PT. Remaja Rosdakarya. 2017)

11 Diah Wardhani. Media Relations: Sarana Membangun Reputasi Organisasi. (Jakarta: Graha Ilmu, 2018).

${ }^{12}$ Kertajaya Hermawan. Memenangkan Persaingan dengan segi tiga Diferensiasi, Positioning, dan Brand. Jakarta : PT. Gramedia Pustaka Utama. 2014

13 Ibid

${ }^{14}$ Uyung Sulaksana. Integrated Mareting Communication. (Yogyakarta: Pustaka Pelajar. 2018).

15 A. Marland. "Strategic management of media relations: Communications centralization and spin in the government of Canada". Canadian Public Policy, 43. (2018): 36-49.

16 K. D. Cahaya Putra. "Strategi Public Relations Pariwisata Bali". 
survive. Marketing communications can tell or show people about how and why the product is used, by what kind of people, and every time. Thus, marketing communication has a very important role for various sectors, especially tourism to describe tourist locations marketed to the target market more broadly. Because marketing communication as a determinant of the success of marketing.

\section{Media Relations}

According Wardhani Media relations is a public relations communication activity in establishing good relations and cooperation with the mass media with the aim of achieving maximum publication. ${ }^{17}$ Simangunsong adds the definition of media relations as a relationship with the communication medium to publish or respond to media interest in the organization. ${ }^{18}$ Yosal Iriantara in his book Media Relations concluded that media relations are part of the external PR that fosters and develops good relations with the mass media as a means of communication between the organization and the public for organizational purposes. ${ }^{19}$ There are five basic principles that become the reference of public relations practitioners or public relations in dealing with mass media: 20

1. Note the deadlines of the mass media.

2. Jengan once talked lies, talked right or silent.

3. Develop closeness and closeness of the relationship with the media.

4. Being a valuable resource person.

5. Do not open unnecessary arguments.

Frank Jefkins once gave tips for press or media relations can be well established, among others as follows: ${ }^{21}$

1. Serving the media (understand and serve the media). Such as providing the required media, information preferred by the media and others. Build a reputation for reliability (building a reputation as a trustworthy person). PR practitioners should always be ready to provide or provide accurate, complete, and reliable materials wherever and whenever necessary.

2. Provide a good copy (provide a good copy). These copies are not only data printed on paper, but also photos, cassettes and videos that are useful for journalists. Expertise in organizing equipment will support community relations activities.

3. Cooperation in providing materials (working together in the supply of materials). Because the work of public relations practitioners is closely related to journalists, both parties must cooperate well.

4. Provide verifications facility (provide verification facility). If journalists are still sanctioned with material given by public relations practitioners, public relations practitioners should be prepared to accept journalists who want to review the material.

5. Building personal relationships with the media (building a solid personal relationship). Honesty, openness and mutual understanding between publicist and journalist should be done.

According Wardhani The purpose of media relations for the organization, namely:22

\footnotetext{
17 Diah Wardhani. Media Relations: Sarana Membangun Reputasi Organisasi.

18 F. Simangunsong, \& Tahir, M. I. "Strategy of Local Government in Tourism Development of Marina Beach in Bantaeng Regency South Sulawesi Province”. Open Journal of Social Sciences, 06, no. 01. (2018). 43-66. https://doi.org/10.4236/jss.2018.61004

19 Yosal Iriantara. Public Relations: Konsep, Pendekatan, dan Praktik. (Bandung: Simbiosa Rekatama Media, 2019).

${ }^{20}$ Ibid.

${ }^{21}$ Nurudin. Hubungan Media Konsep dan Aplikasi.

22 Diah Wardhani. Media Relations: Sarana Membangun Reputasi Organisasi.
} 
1. To obtain the widest possible publicity regarding the activities and steps of a good institution / organization to be known publicly.

2. To get a place in the media coverage (coverage, report, fair, objective and balanced) about the things that apply to the institution / organization.

3. To get feedback from the community about the efforts and activities of the institution / organization.

4. To complete the data / information for the organization's head for the purpose of making an appropriate assessment of the situation or problem affecting the success of the institution / company.

5. Creating a stable and sustainable relationship based on mutual trust and respect.

According to Kriyantono following activities of media relations and forms of activity: 23

a. Press Release, which is written information issued by an agency or organization to be published in the mass media. With the release of press releases, the agency gained publicity regarding the events and issues raised.

b. Press conference, which invites journalists to be alogian, with material carefully prepared by the organizers, while the target of the meeting is the loading of information in the mass media by an invited journalist intermediary. A visit to the press office is to visit a media office for the purpose of establishing a cooperative relationship, knowing the particulars of media work, or to inform everything about the organization, the issues we are addressing, and the activities we need to / do.

c. Press Release / Release Press Release. In this activity informed about the activities of the institution to the press, also held responses or questions journalists. Unlike press conference, press briefings are done on a regular basis, even done for small things, as long as it has news value.

d. Special Event, which holds special activities involving the media, for example, becomes the sponsor of the journalistic writing contest.

e. Press Interview (Interview), which meets journalists and resource persons from institutions to explore information or clarify issues, whether related to organization, mission, and institutional activities.

f. Press Luncheon, PR officials held a lunch for media representatives / journalists, so that on this occasion the press can meet with top management institutions to listen to the development of organizations / institutions.

g. Press Tour, which invites journalists to visit a location, whether located in the neighborhood, or a place or location that has links to the course of the institution.

\section{Methods}

The study used a qualitative study, in which the data to be collected in the form of written words and oral, drawing, and other support of the subject and object behavior examined by reference from Meleong in the journal.24 The focus of the research is on the beach of the district of Lamongan with focus on media relations activities that are applied for improving tourism management including: Writing Press Release, Press Conference, Press Release / Press Release Press, Special Event, Press Interview (Interview), Press Luncheon, Press Tour based on the focus of the study will be tailored to media relations activities that are implemented by the youth organization of Labuhan as the implementer of the public relation of the beach tourism of the debts.

\section{Results and Discussion}

\section{Media Realtions Strategy in Kutang beach}

\footnotetext{
${ }^{23}$ R. Kriyantono. "Research Strategies and Media Relations in Public Relations Practices".

${ }^{24}$ Lexy Moleong. Metode Penelitian Kualitatif Edisi Revisi. Jakarta: Remaja Rosda karya. 2014 
Media relation activities become one of the key in the development of a tourist attraction, each of the attractions competing - the race shows the distinctive characteristics that distinguish the attraction elsewhere. Even today one obje tours can be divided from several spots with different themes to further increase the intensity and enthusiasm of tourist visitors. ${ }^{25}$ This becomes a great job for public relations actors in packing various activities related to the task of public relations in developing a tourist attraction creatively. Here are the results of research from public relations activities karang taruna (local youth organization) of Labuhan village.

1) Writing Press Release

In press release activities have not been maximally implemented, but it has been initiated since November 2017 and in March 2018 informants stated the implementation of this press release writing has been implemented intensively both with local print media that is Tuban post, both in development activities, activities undertaken by educational institutions, agencies, and the general public that have the potential to display an attractive spot on the beach.

2) Press Conference

Along with the initiatives in media utilization, the reefs of the Lome village villages often carry out interesting activities with the aim of increasing interest in beach tourism, the most crowded of which is the visit of the regent and vice regent of Lamongan to plant thousands of mangrove seeds on the coastal cattle in the late 2017. once print and digital media are present to cover. In order for the coverage process to run smoothly and in an orderly manner, the youth organization performed a press conference held at one of the floating stalls around the beach. So, the implementation of this press conference is not maximized, because it still depends on the visit of important people or official who is able to attract the media come in large quantities. However, one informant stated that large-scale implementation was being initiated to be implemented intensively and routinely.

3) Press Briefing / Meeting the Press Routine

Implementation of regular press conferences has not been done effectively, press meetings are only held when there is the best moment involving government or sponsorship on a large scale. Because of limited funds to be the problem of tourism managers in the procurement of activities or large-scale events.

4) Special Event

Special events are being implemented as key incentives to increase the number of tourists. The events that were carried out were Turonggo Massal Dance by all the elementary level students in the Lamongan district, which amounted to 320 students who performed the dance lined from the end of the wooden bridge on the east coast to the west. This dance is very interesting because the elementary students are cunningly dancing on wooden bridges built on the beach. This activity is able to invite tourists to a thousand visitors. Another event held was the mass painting of wooden bridges. This event invites mothers gathering mothers from family welfare education (PKK) Labuhan village to paint the colors of wooden bridges in the afternoon. This activity not only produces rainbow wood bridge from various colors also there is social meaning where this event shows how big role of woman in giving color of life and toughness of woman in executing activity outside of their daily activity. Evet is very siphon visitors to crowded lips and Kutang beach parking area, the most interesting visitors dominated the men who carry the child, where after tracing many visitors of men with their children is the husband of women who participate in painting a massive wooden bridge. And many more special events that can suck a lot of visitors. In addition to the special event, karang taruna (local youth organization) of Kutang beach is also actively carrying out monthly event that invites Lamogan traditional dancers to perform on the Sunday of the fourth week of each month. The goal is to entertain the citizens and tourists at the end of the month, where the end of the month is

\footnotetext{
${ }^{25}$ A. Marland. "Strategic management of media relations: Communications centralization and spin in the government of Canada".
} 
usually a lot of tourists looking for cheap and interesting entertainment, visiting the Kutang beach become cheap tourist solutions but not cheap.

5) Press Interview (Interview)

Press interview is not yet incentive to be applied, only in big event and special event, when there is media then the interview is done. The absence of regular activity at every event to invite the media with the aim of publishing the event. Limited funding and lack of courage to the problems that have not been solved by the manager of the Kutang beach, the lack of media relations and lack of public relations education cacao coastal tourism managers further exacerbate the fears of the managers.

6) Press Luncheon

Limited funding is the main problem in this press luncheon activity, because in entertaining the media parties do not need a small amount of funds, so that managers including the youth are not brave and determined to carry out these public relations activities. So far, if the media present then only served with a simple drink eg coffee, tea, ice degan (coconut) accompanied by typical rural food and typical beach Rujak (salad).

7) Press Tour

This media relation activity requires a large budget so that the manager and the cadet are limited to be able to arrange or intend to carry out this activity, one of the informants insists when there is sponsorship, we will be brave.

Some of the media relation activities above are not maximized due to the lack of education related to public relations and media relation on karang taruna (local youth organization) of Labuhan village as the implementer of public relation of coastal tourism, the lack of courage in wrapping up big event that able to invite media audiences, and the lack of courage in seeking sponsorship. ${ }^{26}$ Another problem that arises is the absence of beach tariff increase tariffs that have been only Rp. 2,000 and Rp. 2,000 for parking fee, if the increase of tourist visit rate is increased, the manager is afraid the number of visitors will decrease and will come out from the beach theme of own debts, where the beach is expected to become the object of cheap and family friendly but not cheap. This concept is fully held by the manager so that still survive with the existing. Though the reality of visitors or tourists will not be objected if the cost retribution has increased during offset by the variety of facilities, cleanliness, safety, and the convenience of visitors take precedence.

\section{Media Marketing Communication Strategy in Creating Sustainable Tourism}

The relationship media strategy is part of the marketing communication strategy. To achieve communication goals in marketing, an effective marketing communication strategy is needed. According to Fill in Asmawaty marketing communication strategies include 3P: push, pull, and profile. ${ }^{27}$ Push strategy is a form of direct communication with the target audience. The focus of push strategy is how to encourage targets to buy the products offered by minimizing the use of advertising. Pull strategy is a marketing communication strategy with the use of a smoother way compared to push strategy, but in pull strategy tends to cost more.

To make the target audience interested in the products offered must use advertising and promotion. Pull strategies are good to use when the demand for a product is high. In contrast to push and pull strategy, in the profile strategy that is emphasized is the procurement of dialogue with stakeholders. ${ }^{28}$

\footnotetext{
26 K. D. Cahaya Putra. "Strategi Public Relations Pariwisata Bali”.

${ }^{27}$ Chris Fill. Marketing Communications: contexts. Contents and strategies. 2nd edition. (New Jersey: Prentice Hall Europe, 1999).

${ }^{28}$ M. K. Nengsih, Ayu, I., Er, M., \& Gayatri, M. "Strategy of Developing Tourism Beach (Case study: Laguna beach , Kaur district". Jelajah: Journal of Tourism and Hospitality 2, no.1 (2020) 12-21. https://doi.org/10.33830/jelajah.v2i1.890
} 
In addition, profile strategy also emphasizes how to make stakeholders continue to know the development or progress of a product. There are many ways to apply a profile strategy. Examples are the use of newsletters, e-mail, and progress reports. Whereas if studied from the understanding of strategy and marketing communication that is, strategy is a whole conditional decision about the action to be carried out, in order to achieve the goal. ${ }^{29}$ In addition, marketing communication is a marketing activity that seeks to disseminate information, influence or persuade, and remind the target market of the company and its products to be willing to accept, buy, and be loyal to the products offered by the company concerned. ${ }^{30}$

Communication strategy is a combination of communication planning and communication management to be able to achieve one goal, with the development of information technology, creating new media that are able to provide new approaches to marketing communication delivery and may be more effective in attracting the attention of consumers. ${ }^{31}$ The emergence of new types of media in marketing activities allows for marketing communication strategies by maximizing the use of new media, to be able to better communicate marketing messages to consumers. Modern marketing requires more than just presenting interesting tours, providing complete facilities, and accompanied by elements that can bring satisfaction. Hopefully certainly one, help sustainable tourism.

A marketing communication strategy is an overview of a marketing goal and the steps to achieve that goal. Before a company does a series of promotions, there are several stages of marketing communication strategy that need to be done by the company. A more detailed description of the process of marketing communication strategies is as follows:

1) Segmentation and Targeting

Erik Berkowitz defines segmentation as the process of dividing a market into clear groups that share the same needs and responding to a marketing action. ${ }^{32}$ Segmentation is the process of dividing the market into smaller groups/ communities, where the members of each group share the same perceptions, desires and motivations for the factors that influence demand. ${ }^{33}$

Segmentation is any homogeneous group called a market segment, namely those who have similarities in buying patterns and habits, how to use products, the needs of users of purchasing motives, how to use products, user needs, purchase motives, purchase goals, attitudes towards products and so on. Market segments show that marketing efforts will be more effective if the units of purchase are grouped into groups / communities, thus providing opportunities to achieve maximum profit (Bahiyah et al., 2018). ${ }^{34}$ Segmentation is necessary so that the company can serve its consumers better, conduct more persuasive communication and satisfy the needs and desires of the intended consumer.

Segmentation is divided into three types, namely geographic, demographic and psychographic segmentation. Geographic segmentation divides markets by geographic unit such as country, state, region, county, city or neighborhood. Demographic segmentation divides markets into groups based on variables such as age, family, family life cycle, gender, income, occupation, education, race, religion, generation, nationality, and social class. While psychographic segmentation is buyers divided into various groups based on psychological traits / personality, lifestyle, social class or values. ${ }^{35}$ People in the same demographic group can

\footnotetext{
${ }^{29}$ Soleh Soemirat, and Adrianto, Elvinaro. Dasar-Dasar Public Relations. (Bandung: Remaja Rosdakarya, 2020).

30 Kertajaya Hermawan. Memenangkan Persaingan dengan segi tiga Diferensiasi, Positioning, dan Brand.

31 Onong Uchjana Effendy. Hubungan Masyarakat Suatu Study Komunikologis.

32 M. K. Nengsih, Ayu, I., Er, M., \& Gayatri, M. "Strategy of Developing Tourism Beach (Case study: Laguna beach , Kaur district"

33 Silvia Rita Fariani and Widodo Aryanto. Panduan Praktisi PR. (Jakarta: Elex Media Komputindo. 2019).

${ }^{34}$ C. Bahiyah, Hidayat, W. R., \& Sudarti. "Strategi Pengembangan Potensi Pariwisata di Pantai Duta Kabupaten Probolinggo". Jurnal Ilmu Ekonomi, 2. (2018): 95-103.

35 H. Kayely, Lagarense, B., Lumettu, A., Manado, P. N., \& Manado, P. N. "The Development Strategy of Tourist Attractions for Promoting Tourism Development"
} 
have very different psychographic profiles. Segmentation also divides the market into groups based on knowledge, behavior, attitudes, use or responses to a product.

The determination of segmentation and target market becomes very important to carry out strategic media in promotion, because the element will determine who will enjoy the tour very clearly and in detail. ${ }^{36}$ This is done to arrange the right and careful strategy in the hope of achieving success in a strategy. The segregation and target market of Kutang beach tourism is from the vulnerable economic class down in which it is evidenced by ticket prices that are only 2,000 rupiah and some points of tourist facilities that are considered still very simple and limited. The lack of availability is due to the lack of government role in its role in building sustainable beach tourism in the coastal areas of Lamongan regency.

Targeting or setting a target market is the next stage of segmentation analysis. Targeting is to establish the market that becomes the center of marketing and promotion of the company's products. Targeting is the process of evaluating the attractiveness of segments and the focus of the bid that is best suited to the group of people, regions or countries that have the most significant response. ${ }^{37}$ Targeting becomes important because companies must have a focus of consumers who have a greater tendency to buy their products. The product of targeting is the target market, which is one or more market segments that will be the focus of marketing activities.

The determination of the target market must involve evaluating each attractiveness of each segment to be entered. Companies must set targets on the segments that have the opportunity to generate profits and customers and have the greatest opportunity to be maintained all the time. ${ }^{38}$ Targeting allows companies to deliver messages appropriately and prevents wasted coverage on people outside the target market. Target consumers are closely related to the existence of media that can be used to reach certain groups or segments in society. The target market has two functions at once, namely selecting the target consumer according to certain criteria and reaching those consumers. 39

\section{2) Positioning and Differentiation}

Positioning is a communication strategy that deals with how an audience puts a product, brand or company in its mind, in its imaginary realm, so that the audience has a certain judgmen. ${ }^{40}$ Positioning is a statement of what the product means, buyer perception, and attempts to clarify the advantages of all product attributes to attract buyers. Positioning is the stage of how to determine the position of the product in the minds of consumers, so that prospective consumers have a certain judgment and identify themselves with the product.

Positioning is an attempt to shape the image of a product appearing in relation to other products in the market or positioned against competing brands in the consumer perception map. A perception map defines the market in terms of how buyers perceive the key characteristics of a competing product. ${ }^{41}$ This perception map will be the basis for buyers in using products such as price and quality. Good marketing should leave a very strong impression on the product from the consumer side.

At this stage, Kutang beach tourism has tried to present the difference from the beach tourism around it, including in terms of making a unique name, The provision of color bridge

\footnotetext{
${ }^{36}$ Asmawaty. "Beach Tourism Destinations Promotion Strategy Tthrough Social Media Influencers in Bulukumba Regency".

${ }^{37}$ F. Qorib, \& Syahida, A. R. "Strategi Museum Angkut Kota Batu Dalam Membagun Hubungan dengan Media Massa." Reformasi: Jurnal Ilmiah Ilmu Sosial dan Ilmu Politik 7.no.1 (2017) :47-55.

38 Philip Kotler; Armstrong, Garry, 2008. Prinsip-prinsip Pemasaran, Jilid 1, (Jakarta: Erlangga, 2008)

${ }^{39}$ C. Bahiyah, Hidayat, W. R., \& Sudarti. "Strategi Pengembangan Potensi Pariwisata di Pantai Duta Kabupaten Probolinggo".

${ }^{40}$ F. Simangunsong, \& Tahir, M. I. "Strategy of Local Government in Tourism Development of Marina Beach in Bantaeng Regency South Sulawesi Province".

${ }^{41}$ K. D. Cahaya Putra. "Strategi Public Relations Pariwisata Bali".
} 
facilities that surround the beach, the provision of some typical culinary, and certainly lies in management involving local residents. Differentiation is evidence that Kutang beach tourism seeks to present the characteristics and the action is responded well by the community. Evidently after positioning and differentiation there is an increase in visits. Moreover, currently there have been many selfie spots that can be used to help maximize the media relationship strategy applied and very clearly able to ease the burden of promotion that must be done.

\section{E. Conclusion}

It is time for tourism to clean up to be able to present the characteristics and uniqueness that distinguishes between one with the other tourism places. It becomes the motivation of managers to create, create these characteristics in order to be able to compete in the world of tourism. Kutang beach Lamongan district has been tidying up to make beach tourism family friendly and begin to erode the negative meaning of coastal history of its own debt. Kutang beach has been transformed by youth village into a tourist attraction and educational. In addition, there is a beach with white sand, mangrove forests on the beach, as well as a rainbow wooden bridge built above the beach to connect east coast lane to north west of Kutang beach. Although not officially managers formed public relations to promote Kutang beach, so long coral cadets become the publicist. Public relations are not separated from the role of media, media relations become gauge activity and maximization of public relation activities. Here are some media relation activities such as Press Release Writing, Press Conference, Press Release / Press Release, Special Event, Press Interview (Interview), Press Luncheon, Press Tour. From the activities of media relation, the application of the chain of credits that have been running incentives and in the category of good assessment is the activity of Press Release Writing, Press Conference and special event, while other activities such as Press Briefing / Press Release Press, Press Interview, Press Luncheon, Press Tour has not been maximally implemented because of various obstacles such as lack of education related to public relations and media relation, lack of courage in packing big event able to invite media, and lack of courage in seeking sponsorship. Another problem that arises is that managers do not want to raise levy cost, whereas the reality of tourists and visitors do not mind the increase in entry fees, as long as balanced with the development and development of an increasingly professional tourism.

\section{References}

Asmawaty. "Beach Tourism Destinations Promotion Strategy Tthrough Social Media Influencers in Bulukumba Regency”. International Journal of Papier Review 2, no.4. (2021). 56-69

Bahiyah, C., Hidayat, W. R., \& Sudarti. "Strategi Pengembangan Potensi Pariwisata Di Pantai Duta Kabupaten Probolinggo". Jurnal Ilmu Ekonomi, 2. (2018): 95-103.

Effendy, Onong Uchjana. Hubungan Masyarakat Suatu Study Komunikologis. Bandung: PT. Remaja Rosdakarya. 2017

Fariani, Silvia Rita dan Widodo Aryanto. Panduan Praktisi PR. Jakarta: Elex Media Komputindo. 2019.

Fill, Chris. Marketing Communications: contexts. Contents and strategies. 2nd edition. New Jersey: Prentice Hall Europe. 1999

Hermawan, Kertajaya. Memenangkan Persaingan dengan segi tiga Diferensiasi, Positioning, dan Brand. Jakarta: PT. Gramedia Pustaka Utama. 2014.

Iriantara, Yosal. Public Relations: Konsep, Pendekatan, dan Praktik. Bandung: Simbiosa Rekatama Media. 2019.

Kayely, H., Lagarense, B., Lumettu, A., Manado, P. N., \& Manado, P. N. “The Development Strategy of Tourist Attractions". Jurnal Hospitaliti dan Pariwisata 3, no.2. (2016). pp.114-232 
Kotler, Philip; Armstrong, Garry, 2008. Prinsip-prinsip Pemasaran, Jilid 1, Jakarta: Erlangga. 2008

Kriyantono, R. "Research Strategies and Media Relations in Public Relations Practices". Jurnal Komunikatif, 8. (2019): 178-190.

Kustadi. Public Relations Perusahaan: Kajian, Program, dan Implementasi, Bandung: Yayasan Nuansa Cendekia. 2014.

Marland, A. "Strategic management of media relations: Communications centralization and spin in the government of Canada". Canadian Public Policy, 43. (2018): 36-49.

Moleong, Lexy. Metode Penelitian Kualitatif Edisi Revisi. Jakarta: Remaja Rosda karya. 2014.

Nengsih, M. K., Ayu, I., Er, M., \& Gayatri, M. "Strategy of Developing Tourism Beach (Case study : laguna beach , Kaur district". Jelajah: Journal of Tourism and Hospitality 2, no.1 (2020) 1221. https://doi.org/10.33830/jelajah.v2i1.890

Nova, Firsan. Strategi Public Relation: Menghadapi Krisis,Mengelola Isu, Membangun citra, dan Reputasi Perusahaan. Jakarta: Rajawali Grafindo Persada. 2010.

Nurudin. Hubungan Media Konsep dan Aplikasi. Jakarta:Raja Grafindo Persada. 2018.

Putra, K. D. Cahaya. "Strategi Public Relations Pariwisata Bali”. Jurnal Ilmu Komunikasi, 5. (2013).

Qorib, F., \& Syahida, A. R. "Strategi Museum Angkut Kota Batu Dalam Membagun Hubungan dengan Media Massa." Reformasi: Jurnal Ilmiah Ilmu Sosial dan Ilmu Politik 7.no.1 (2017) :4755.

Shimp, Terence. Komunikasi Pemasaran Terpadu dalam periklanan dan Promosi. Jakarta: Salemba Empat. 2014.

Simangunsong, F., \& Tahir, M. I. Strategy of Local Government in Tourism Development of Marina Beach in Bantaeng Regency South Sulawesi Province. Open Journal of Social Sciences, 06(01). (2018). 43-66. https://doi.org/10.4236/jss.2018.61004.

Soemirat, Soleh dan Adrianto, Elvinaro. Dasar-Dasar Public Relations. Bandung: Remaja Rosdakarya. 2020.

Sulaksana, Uyung. Integrated Mareting Communication. Yogyakarta: Pustaka Pelajar. 2018.

Wardhani, Diah. Media Relations: Sarana Membangun Reputasi Organisasi. Jakarta: Graha Ilmu. 2018. 